Conference Paper presented at the 27th International GERPISA Conference, Paradigm shift? The Automotive Industry in Transition, 12-14 June 2019, Paris, France.

Later published in:

Citation: B. Jetin (2020). "Who will control the electric vehicle market?" International Journal of Automobile Technology and Management, 20 (2), p 156-177. DOI: https://doi.org/10.1504/IJATM.2020.108584

\title{
Who will control the electric vehicle market?
}

\begin{abstract}
.
The second automobile revolution, the age of electrification and digitalisation, is on its way. It is a gradual transition and not a sudden break. However, millions of electric vehicles (EVs) are now being sold, and the EV market is becoming a mass market propelled by economies of scale. It is reflected in the drop in the cost of batteries which will bring the price of EVs on a par with the price of conventional vehicles in the coming decade. Nonetheless, two interrelated issues have been underestimated and will now decide who will play a dominant role and benefit the most from the EV market. The first is the relative scarcity of raw materials from which batteries are made. The second is that the primary EV market is China which gives its companies a strategic advantage for the supply of critical metals and the large-scale production of batteries. Our research analyses the fundamental role of natural resources for the control of the EV market and the response of governments to ensure access to them. We show the importance of industrial and diplomatic policies in a context of geostrategic rivalries of large powers.
\end{abstract}

Keywords: electric vehicle, battery electric vehicle, lithium-ion battery, materials, battery makers, carmakers

\section{Introduction: The second automobile revolution is underway}

For several decades, the electric car has been the "eternally emerging" new technology (Fréry, 2000) as several earlier attempts in the 1990s and early 2000s failed to turn it into a mass market. The push and pull motives have always been the reduction of carbon emissions and bouts of soaring prices of gasoline. However, the intense lobbying of carmakers has usually succeeded to gut the bills aimed at reducing fossils fuel consumption, and the reversal of prices of gasoline have dampened consumers' interest for clean and energy-efficient cars. Things have started to change after the great recession of 2009, and conditions are in place today for the electric car to be the vehicle of the "second automobile revolution" (Freyssenet, 2011, 2009). Freyssenet had listed four main conditions for a car revolution: (1) a systemic crisis of the previous transport system, (2) the emergence of various solutions thanks to innovations coming from other industrial sectors, (3) the formation of a coalition of economic, political and social forces to impose a solution, (4) the macro-economic decisions and the public policies for a broad diffusion of a chosen standard.

Events never exactly happen as predicted, but ten years after the publication of Freyssenet's seminal book, the electric car is moving from the margins where it was previously confined. 
(1) The petrol car transport industry is still confronted to a systemic crisis although the shale oil revolution in North America has refuted the peak oil theory and its prediction of a sharp increase of the prices of gasoline at the world level (Fessler, 2019). In a context of global economic recovery after the great recession of 2009, this has prompted one of the most prolonged expansion of the automobile market in contemporary history. At global level, new sales of all types of vehicles have grown at the average rate of $4.2 \%^{1}$ (OICA, 2019). American and Chinese drivers have enjoyed a decade (2010-19) of cheap gasoline, which has boosted the sales of SUV and premium cars. It is less the case in Europe where high prices of gasoline, in a context of economic hardship, have led to a crisis of affordability of car ownership (Jetin, 2015) and political tensions. In many developing countries, the low price of gasoline is the result of massive subsidies that governments can no longer sustain. More, the last cycle of expansion of automobile sales has magnified congestion, pollution and other negative externalities that existed previously. The shale oil revolution has delayed the moment of truth of the petrol car transport system but has not provided a solution to its crisis.

(2) Innovation has led to a convergence towards electricity, the Battery Electric Vehicle (BEV) and connectivity to replace oil and the Internal Combustion Engine (ICE). Alternative solutions such as agro-fuels cannot compete (Proff, 2011) (Amatucci \& Spers, 2010). Agrofuels are limited in volume and are adjuvants to oil. They will decline when oil demand starts to shrink, possibly after 2030 (British Petroleum, 2018). Hydrogen is not viable energy for the proximate future. Toyota, Honda and Hyundai's progress in fuel-cell hydrogen ${ }^{2}$ technology is hampered by the present incapacity to produce clean and cheap hydrogen at a large scale. The majority of carmakers focus their efforts only on batteries. They are encouraged by innovations in renewable energy, battery storage, smart grids and connectivity, which strengthen its advantages.

(3) A heightened global concern for climate change has led to the emergence of a coalition of economic, politic and social forces which is conducive to the fast development of the electric vehicles. The signature of the 2015 global Paris agreement ${ }^{3}$ has eased the adoption in 2019 of the EU Car CO2 standards for 2025-30 (European Commission, 2019b) ${ }^{4}$. In China, a similar policy of earned credit system is also introduced in 2019 (Sun, 2019) ${ }^{5}$. These were inspired by a pioneered policy initiated by California in 1990, updated in 2012 and adopted by 9 other states in the USA (California Air Resources Board Board, 2019) ${ }^{6}$. The "diesel gate" which erupted in 2015 (McGee, 2018), was an additional motive for many countries and cities to announce that sales of new conventional petrol and diesel cars and vans would be banned between 2025 and 2040. Most of the light-duty vehicles must be zero-emission by 2050 at the latest (House of Commons, 2019) ${ }^{7}$. This political decision, plus the necessity to repair their tarnished image, is forcing many carmakers to change their strategy and to give priority to Electric Vehicles (EVs). For instance, in March 2019, Volkswagen, the top number one producer at world level, announced $70 \mathrm{EV}$ model launches in the next ten years, up from 50 previously. By 2030, it expects 40 per cent of sales to be battery vehicles. As a result, 15 to 22 million EVs will be built on electric platforms to achieve $\mathrm{CO}_{2}$ neutral balance (VW, 2019). This decision, followed by BMW and Daimler, comes as a signal for part and component makers that time has come to invest massively in the battery value chain if they want to stay in business. This is a radical change compared to the situation observed by Freyssenet (2012, p. 310) ten years ago when only a minority of carmakers (Renault-Nissan, Chinese and Indian carmakers) were producing BEV. The environmental constraint has been finally more effective to speed up the transition to electromobility than a rising price of gasoline that so far has failed to materialise.

(4) Prolonged quantitative-easing monetary policies, massive government subsidies to the purchase of EVs, and public policies supportive to innovation have combined to kick-start the mass marketing of EVs. Low-interest rates have been a boon for the recovery of the 
automobile market after the great recession of 2008-09. They are still critical for the purchase of EVs, which are still more onerous than conventional cars. That is why public subsidies are initially trying to close the gap. They were decisive in China to both decide Chinese companies to invest in the EV value chain and to encourage potential customers to purchase them. Subsidies are also used as an industrial policy tool to channel R\&D towards the improvement of batteries, to extend their range and reduce their cost.

The present paper builds on the theoretical approach developed by Freyssenet and Boyer and Freyssenet (Boyer \& Freyssenet, 2002) although it does not look at the profit strategy of individual carmakers. While most of the literature look at the demand side, it takes stock of progress made toward the adoption of the electric vehicle and focus on the supply side and in particular on one condition that has been so far underestimated: the limited availability of some critical materials for the production of batteries. Resources shortages could increase battery costs at a time when the affordability of EVs will be essential for their success. Like Freyssenet (2012, p. 318), we consider that any scenario of transition to electromobility, whether a progressive or rupture scenario, must take seriously the geopolitical and not only the technical conditions into account. We believe that access to critical resources is one of the key issues of geopolitical and trade tensions between the great powers that happen to be the primary automobile producers. Our paper relies on a systematic review of the academic literature and secondary sources and our calculations of resources availability. Section 1 looks at the most recent growth forecasts of the EVs market. Based on these projections, section 2 estimates the potential constraints that resources availability will impose on the development of the EV market. Section 3 reviews the public policies that states have adopted to secure resources supply and promote a local battery industry. We conclude that only countries or regional groupings that have adopted comprehensive policies to ensure access to critical metals and develop local battery making have a chance to play a leading role in the electric vehicle market.

\section{The emergence of a mass market electric vehicle}

$\mathrm{EVs}^{8}$ sales are soaring. In 2018, 2.2 million EVs were sold worldwide up from 0.4 million in 2014. The total fleet in circulation was 5.6 million up from 0.8 million in 2014 (Nieder \& Püttner, 2019). With around 2.3\% of total sales, it is still marginal in terms of global market share. However, in terms of absolute numbers, it is becoming high enough to start reaping the benefits of mass production.

At world level, many forecasters reckon that EVS will soar in the 2020s and become the majority during the 2040s. Bloomberg New Energy Finance has published the most optimistic projection: it expects annual passenger EV sales to rise to 10 million in 2025, 28 million in 2030, and 56 million by 2040. By that time, 57 per cent of new car sales and a third of the global light-duty vehicle fleet will be electrified. The EVs car fleet will then amount to 530 million units (Bloomberg New Finance, 2019). Other forecasters anticipate lower vehicle fleets, but they all made significant upward revisions to their previous estimations. By 2030, the International Energy Agency (IEA) expects passenger EVs to reach 23 million sales and a 130 million fleet, according to its "New Policies Scenario", which aims to illustrate the consequences of announced policy ambitions (IEA, 2019). In a much more optimistic scenario, the EV30@30 Scenario, EV sales reach 43 million, and the stock is more than 250 million ${ }^{9}$. By 2040, OPEC expects a fleet of 266 million passengers EVs, BP 300 million, and ExxonMobil 100 million ${ }^{10}$ (Cheung, 2017; The Economist, 2017).

The Battery Electric Vehicles (BEVs) are turning into the dominant segment of EVS. In 2018, they already accounted for 64\% of world electric car fleet up from 50\% in 2012 (IEA, 
2019, p. 35). It comes from the healthy growth of the Chinese market, which is dominated by BEVs (76\%). In the USA, BEVs represents $66 \%$ of EVs thanks to the predominance of Tesla, which only sells BEVs. In the EU, their share was close to half in 2018 but is expected to rise to around 60\% of total EU EV production in 2025 (Transport \& Environment, 2019).

Batteries play, therefore a vital role in the EV value chain. In 2018, they accounted for about $40 \%$ of the price of a car in the medium segment price and were the main reason why a BEV costed more than an ICE vehicle (Curry, 2017). Innovation, learning curve, and economies of scale have the potential to reduce their cost drastically and to make BEVs cheaper than conventional cars as early as 2022, with further improvement in the subsequent years. In 2030, the battery cost share could be as low as $18 \%$ according to Curry $(2017, \text { p. } 8)^{11}$, which is below than the 25\% cost share of an ICE (Schade \& Mader, 2016). In monetary terms, the US Department of Energy had calculated that this moment would happen once battery costs fall below $\$ 130$ per kWh. Many specialists believe that battery costs will reach $\$ 150$ in 2020 and $\$ 100$ in 2025, up from $\$ 1,100$ in 2010 (Nykvista, Spreib, \& Nilssona, 2019) ${ }^{12}$. Using dedicated platforms for EVs will also increase their competitiveness and performance (Muniz \& Belzowski, 2017). Knowing that the operational cost of a BEV is already much lower than the one of an ICE-vehicle, the total cost of ownership of BEVs have therefore the potential to come very close to cost parity with ICE vehicles between 2025 and 2030 (Berggren \& Kågeson, 2017). It will remove a significant obstacle to their massive adoption and strengthen their capacity to replace conventional vehicles. The cost parity depends on several factors like the battery range, the battery cost, the number of $\mathrm{km}$ per year, and the price of gasoline. Interestingly, parity is reached "at higher battery prices for larger vehicles (e.g. sport-utility vehicles [SUVs]) than cars, due to the increased relative benefits of electrification for heavier vehicles" (IEA, 2019, p. 168) ${ }^{13}$. It means that the popularity of SUV is not an insuperable obstacle to the EVs' success.

However, the mass production of BEVs, and more generally of EVs, has still one fundamental obstacle to overcome. Its upturn will result in a strong demand for mineral ores, which for some of them are in limited supply.

\section{Lithium-Ion Batteries (LIBs) are material dependent.}

The LIB value manufacturing chain consists of four main segments: (1) raw material mining; (2) cell component manufacturing; (3) cell manufacturing; (4) Battery pack manufacturing. The majority of cells are assembled for use in portable electronic devices. However, a fast-growing share is destined for use in battery packs for electric vehicles. At the end of their life, LIB can be recycled or employed in a second use application (e.g. for stationary energy storage) (Lebedeva, Di Persio, \& Boon-Brett, 2017, p. 5). Raw materials, once extracted by mining companies, have to be refined through chemical processing. The refinery is operated by the same mining companies or by independent chemical companies. Several sources indicate that the share of total materials in the cost of a finished LIB pack is high. "It lies between $60 \%$ and $80 \%$, with $66 \%$, appearing to be a key number" (Wentker, Greenwood, \& Leker, 2019, p. 12). Processed materials are used in the production of the various cell components, which include an anode (positive electrode), a cathode (negative electrode), separated by a liquid organic electrolyte, and a separator. The anode typically consists of various carbonaceous materials, in particular, natural and artificial graphite. The cathode is the most critical component for the battery cell performance. It costs twice as much as the anode. It is made of various chemical combinations of oxidized metals. The most frequent chemistries are: (1) lithium-cobalt-oxide (LCO), (2) nickel-cobalt manganese (NMC), (3) nickel cobalt aluminium (NCA), (4) lithium manganese oxide (LMO) and (5) lithium iron phosphate (LFP). Table 1, adapted from DeCarlo and Matthews (2019), presents critical features of these combinations. 
Table 1, here

One can see that LFP and LMO have rather low energy density compared to the other chemistries. LFP also has the disadvantage to offer a relatively low number of cycles, which means that its longevity is shorter than other chemistries. It is mainly used in China for electric cars, vans and buses, and grid applications. BYD also used it in its early EVs models. LMO was also used in first generations of EVs but is being phased out due to its poor energy density and concerns of stability.

In comparison, NMC, LCO and NCA combine a higher energy density and a longer life expectancy making them the chemistries of choice for new generations of EVs. Table 2, adapted from Blomgren (2017) and (Reinhardt, García, Casals, \& Domingo, 2019), show that Tesla privileges NCA (Nickel-Cobalt-Aluminium) because it provides high power capacity and longrange. However, Tesla models are expensive and belong to the premium category. Most other carmakers opt for NMC (Nickel-Manganese-Cobalt) combinations.

Table 2, here

The trend is to try to reduce the proportion of cobalt in the chemistries (Jaffe, 2017). The reason is that resources are limited, making cobalt expensive, and located in politically risky countries. It is why LCO, which has the highest share of cobalt, is progressively abandoned by carmakers and cobalt is progressively replaced by nickel which allows higher energy density. Table 3, adapted from Olivetti, Ceder, Gaustad, and Fu (2017), show that NCA has a limited share of cobalt (14\%) while NMC-111, already in use and NMC-622, recently introduced, include a much higher share (respectively 42,6 and $21,8 \%)^{14}$.

Table 3, here

In terms of cobalt content, only NMC-811 can compete with NCA. However, it is not technically ready and is expected to be in use in the middle of the 2020s. It left the LIB industry exposed to significant risks.

These risks include the risk of supply reduction associated with the risk of demand increase, the concentration risk and the political risk (Helbig, Bradshaw, Wietschel, Thorenz, $\&$ Tuma, 2018). The risk of supply reduction comes from the risk of physical depletion of materials, which may be exacerbated by a surge in demand. Table 4 gives an illustration of the issues at stake for a mix of the most recent chemistries.

Table 4, here

We estimate the material demands for the IEA "New Policy" scenario which rests on the hypothesis of 23 million-unit sales and the "30@30" scenario, which assumes 43 millionunit sales for the year 2030. Following Harvey (2018, p. 665), we use the data published by United States Geological Survey to calculate the lifespan as the number of years that the current reserve or resource ${ }^{15}$ would last based on the current rates of mining plus the additional mining required to meet EVs metal demand.

The main conclusion of Table 4 is that lifespans are very short for cobalt and nickel. The reserve for these two metals would be depleted in respectively 22 and 28 years for the New Policy scenario and 14 and 22 years for the $30 @ 30$ scenario. It is too short to be sustainable. In terms of resource, the lifespan is higher but still short for nickel. The reserve lifespans are 
slightly better for lithium and manganese but are still too low to be sustainable in the long term. Lithium is the only metal for which the resource lifespan is more than a century if it can really be extracted profitably.

Our estimates are based on moderate scenarios for which EVs sales account for around a quarter of total sales in 2030. It means that the transition to higher shares of EVs to meet the Paris agreement and the target of $100 \%$ of zero-emission vehicles in 2050 would further press the automobile industry against material supply constraints. The solution can only be a mix of technical progress to reduce the metal content and the use of more abundant metals, a decline of car ownership and the rise of car-sharing and other forms of new mobility and the development of public transport. Recycling is theoretically a solution to material scarcity but is so far limited in practice. A LIB lifespan is around 8 years and should improve. It implies that if an EV mass market takes off in the 2020s, a large amount of recyclable spent batteries will only be available in the 2030s. So, it cannot be a short-term solution. Recycling costs are relatively high, around US $\$ 1,000$ to US $\$ 2,000$ per ton, which means that the metal recovery cannot pay for recycling cost (Ajanovic \& Haas, 2018). These high costs have also to be compared with the raw material extraction cost, which may be lower in some cases. This is the case for lithium which makes recycled lithium comes as a by-product of more expensive materials like cobalt. Overall, the recycling of spent batteries is very low. It is less than $10 \%$ in the USA and less than $1 \%$ in the EU. (Rosendahl \& Rubiano, 2019). The fact that the current recycling targets are based solely on mass, in the EU case, and not on the rarity of critical metals does not help to improve the recycling rate (Ortego, Valero, Valero, \& Restrepo, 2018).

Our results are limited to scarcity and depletion, but they complete and confirmed other studies which focus on material criticality and use different methodologies. For instance, the Royal Society of Chemistry in the United Kingdom (RSC) estimates a "relative supply risk" index of minerals and non-minerals, which ranks from 1 (very low risk) to 10 (very high risk). "It is calculated by combining the scores for crustal abundance, reserve distribution, production concentration, substitutability, recycling rate and political stability scores". Three materials needed for the production of LIB have a very high or high supply risks (Graphite, 8.1, Cobalt, 7.6, and lithium, 6.7). Two have a medium supply risk (Nickel, 6.2 and Manganese, 5.7). Only one, aluminium, presents a low risk (4.8) (RSC, 2017).

The latest Mineral Critical List published in the USA in 2018 is based on an early warning methodology. The list includes aluminium, cobalt, cobalt, lithium and manganese. Finally, since 2011, the Joint Research Centre in the European Commission (JRC) establishes a list of critical raw materials (CRMs) for the EU, which is updated and reviewed every three years. The list is based on the economic importance, for instance, for the clean energy transition, and the supply risk for the EU, in particular, the dependence on imports (European Commission, 2019a). In 2017, there were 27 critical raw materials, among which 5 are involved in LIB making: cobalt, natural graphite, silicon metal, phosphorus and fluorspar. Lithium is anticipated to become critical due to the expected sharp increase in demand (Blagoeva, C., Wittmer, Huisman, \& Pasimeni, 2019). One of the main reasons for the high supply risk of most of the materials implied in LIB making is the geopolitical risk.

\section{A high level of concentration of geopolitical risk}

A high concentration risk compounds this high level of supply and demand risk for most of the LIB materials. "In 2016, 32 countries accounted for all global production of lithium, graphite, nickel, manganese and cobalt, with $50 \%$ of production originating in one or two countries for all but one element" (Mayyas, Steward, \& Mann, 2019, p. 2). In particular, 50\% of cobalt comes from the Democratic Republic of Congo; 65\% of graphite comes from China; 
lithium is concentrated in two countries, Australia (41\%) and Chile (34\%); manganese in South Africa (34\%), China (17\%) and Australia (16\%). For nickel, the Philippines accounted for (22\%), while Canada, Russia, and Australia each accounted for 9 to $11 \%$ of the total (Mayyas et al., 2019, pp. 2-3). In 2018, Indonesia had become the top 1 producer of nickel and possessed the most abundant reserves (Opinion Lex, 2019).

An industrial concentration exacerbates this geographical concentration. An oligopoly of companies produces most of the world's lithium often referred to as the "Big Three": Albemarle (USA), Sociedad Quimica y Minera de Chile (SQM, Chili) and FMC (USA). They were recently joined by two Chinese mining companies Tianqi and Ganfeng. Together, they refine more than $60 \%$ of lithium and operate some mines jointly. For instance, Australia's largest lithium mine, called Greenbushes, operated by Talison Lithium, is majority controlled by China's Tianqi Lithium, while Albermarle owns 49\% (Barrera, 2019). In Chili, Tianqi runs a mine with SQM. Cobalt production is less concentrated than nickel. In 2017, the top three players, Glencore (British-Swiss, 22\%), Gecamines (DRC, 9\%, a state-controlled company) and China Molybdenum (China, 7\%, partially owned by the Chinese government) account for less than $40 \%$ of global production (Azevedo et al., 2018, p. 12). It does not reflect the real influence of China on cobalt mining. "Seven of the ten largest producers in DRC as of 2016 were Chinese-owned, and the Chinese State Reserve Bureau stockpiles the mineral" (Behrmann, Farchy, \& Dodge, 2018, p. 6). This high industrial concentration puts the mining companies in a strong position when prices soar. Carmakers are forced to negotiate long-term purchase contracts with mining companies to supply the metals to their battery manufacturers. They need to make a compromise on the price because mining companies cannot be pressured as easily as part makers.

This geographical and company concentration risks leads to a significant political risk, which comes from a broad set of countries, from the very poor and politically unstable to the powerful and politically stable. For instance, nickel prices hit a five-year high after Indonesia decided a ban on the exports of nickel in 2020 to attract more processing business rather than just exporting raw materials. Jakarta wants to step up efforts to build a local refinery industry as it plans to build an electric car industry and to become Asia's hub for electric vehicle production (Hume, 2019). Another worrying case is the Democratic Republic of Congo (DRC), which is a country plagued by armed conflicts, corruption and war crimes. Human rights NGOs denounced the use of child labour in the extraction of cobalt and other ores (Wilson \& Hume, 2019). It is not the kind of image that carmakers want to see attached to the EVS they are marketing. In April 2019, BMW announced that it would source its cobalt for its electric cars from Morocco and Australia and not the DRC. (Sanderson, 2019a). The DRC has also decided to double its tax on revenues of mining companies (Sanderson, 2019d) which means the payment of royalties (10\%) and super profit taxes (50\%).

Other countries, like China and Russia, are involved in political and commercial conflicts $^{16}$. According to Benchmark Minerals Intelligence, in April 2019, China refined 60\% of global lithium (quoted in Sanderson (2019b). It is the leading importer of cobalt ore (40\%) and refines four-fifths of the cobalt at world level. It was until recently the most crucial supplier of refined cobalt to the USA. The critical role that China plays in the supply of cobalt is also a concern for Japanese and Korean battery makers. They fear that in case of political tensions, China may restrict or even ban exports to Japan and Korea which would disrupt their production of cells ${ }^{17}$. China also owns $30 \%$ of rare earths global reserves and produces $90 \%$ of rare earths (Coles, 2019). These are needed for the production of magnets for EVs, battery storage, wind turbines, many electronic appliances, and in defence and aerospace technologies. Recently, China has implicitly threatened to use rare earths in the trade conflict with USA (Hornby \& Sanderson, 2019). It has prompted the USA to launch an alliance with Australia to reduce 
reliance on Chinese rare earths that Chili refuses to join because China is one of its main client (Dempsey \& Sanderson, 2019).

These risks may materialise all the more easily that some rare earths and other minerals, like lithium and cobalt, are produced as co-product or by-product. They depend on the mining of a host metal at the level of $85 \%$ for cobalt and $52 \%$ for lithium (Nassar, Graedel, \& Harper, 2015). For example, the Democratic Republic of Congo (DRC) produces 50\% of raw cobalt as a by-product of nickel, iron and copper mining. If, for instance, the demand for nickel were to drop, the production of cobalt would diminish too, especially as the concentration of cobalt in nickel ore is low. However, if the demand for cobalt rises, the production of nickel will not necessarily increase, making cobalt scarce and his price skyrocketing.

In summary, the main minerals involved in battery production, in particular, nickel and cobalt, may be subject to unforeseen restrictions. It leads to high short term volatility of prices with a significant effect on cathode prices and battery packs. Wentker et al. (2019, pp. 10-12) show that between January 2017 and March 2018, when cobalt prices have tripled while nickel prices increased modestly, cathodes intensive in cobalt like NMC-111 and NMC-622 increased in price by respectively $63.6 \%$ and $44 \%$. Those containing minimal cobalt such as NCA and NMC-811, increased by a smaller margin, respectively $36,2 \%$ and $28 \%$. LNMO containing nickel but no cobalt increased only $4.7 \%$, and LMO and LFP containing neither cobalt nor nickel remained stable. Lithium is a different case. Due to its small share in total materials (see above Table 3), it has a small impact on the cost of cells. According to Ciez and Whitacre (2016, p. 311 ) and $(2017$, p. 279$)$, an increase from $\$ 7.5 / \mathrm{kg}$ to $\$ 25 / \mathrm{kg}$ (233\%) of the price of lithium carbonate leads to an increase of 5 to $7 \%$ of the cell price, depending on the chemistries and format. The lithium prices would have to increase to $\$ 36 / \mathrm{kg}$ or $\$ 87 / \mathrm{kg}$ to induce a $15 \%$ increase in cell cost.

At short-term, the price-volatility of the primary materials will remain, alternating periods of rising, as between 2017 and 2018 when the surge in China drove the EV market, and periods of fall in prices, as the one which started in 2019 with the decline of the automobile market and removal of EV subsidies in several markets. Mining companies react by shutting mines when prices are low and investing in capacity with lag when prices rise. This short-term volatility indicates that the prices of batteries cannot be assumed to remain stable or decline steadily. When the EV mass market takes off, one may expect an upward trend in the price of all the primary materials that will also be sustained by the energy transition towards renewable energy and battery storage.

It is the long term scenario that Liu et al. (2019) explore in the case of China and the example of lithium. They use a system dynamics model, including both the electric energy storage and $\mathrm{EVs}^{18}$ markets to forecast the gap between supply and demand and the resulting price evolution of lithium for batteries. The model includes the recycling of spent lithium. Their result shows that during the first nine years, the price of lithium remains stable. When the demand for EVs takes off, the price of lithium rises during the next 15 years at an increasing rate. It is only after 20 years that the price of lithium begins to decrease as the supply adjusts to the demand gradually. The adjustment is mainly operated thanks to growing imports which expose China to market risks. This decline in price does not last because the electric energy storage market picks up and drive the price of lithium up again. It only stabilises after 40 years. It is, of course, a modelling exercise but the idea that the first years of the EV mass market will see a rise in the price of the leading materials is very plausible.

To secure their supply of lithium and other materials at a stable price, some carmakers are buying stakes in mining projects or even establish joint ventures with mining companies. For instance, Great Wall Motor bought a stake in the lithium mine of Pilbara, Australia. Since 2014, Toyota has a joint venture with Orocobre, an Australian miner, to extract lithium at Olaroz Lithium Facility in Argentina. The joint company later constructed a lithium hydroxide 
plant in Nahara (Japan) to convert the lithium carbonate produced in Argentina. The output is intended for Japanese battery producers, such as Sumitomo's cathode plant nearby and a future battery manufacturing facility built in a joint venture between Toyota and Panasonic. Toyota has a long-standing partnership with Panasonic for the development of next-generation batteries and has a stake in Sumitomo, who is the largest Japanese nickel smelter (Inagaki, Henry, \& Charles, 2018). Tesla has signed an agreement with Bacanora, a Canadian firm, to purchase lithium hydroxide from a mining project in Sonora, northern Mexico. Bacanora will receive much-needed capital from Ganfeng Lithium, China's second-biggest lithium producer, which has also secured agreements to supply Tesla and Volkswagen. Ganfeng has signed a three yearcontract with Tesla to supply its Giga factory in Nevada. Ganfeng will also supply lithium to Volkswagen and its battery suppliers for the next ten years (Volkswagen Group News, 04/05/2019). In its statement, Volkswagen declares that it expects the global lithium demand to more than double by 2023 and that the agreement is a milestone in supply security for the group. Also, the two companies will cooperate on battery recycling and solid-state batteries. In summary, this scramble for materials shows that some carmakers are getting ready for a future scarcity of critical metals and its associated rise of cell cost.

\section{The importance of public policies}

The dominant position of China in the global EV market is the result of its comprehensive public policy, i.e. a policy which aims at developing all the segments of the battery value chain, from raw materials to battery packs. This policy was motivated by China's concerns about rising oil dependence. In 2009, China adopted a Strategic Petroleum Reserve (SPR) Programme and a policy to develop the local EVs production (Kong, 2016) (H. Wang \& Kimble, 2011). Dramatic air pollution, urban congestion and the need to find new sources of development to offset the growth slowdown led the Chinese authorities to strengthen the EV policy. In 2015, when China overcame the USA as the world's top oil importer, EVs were one of ten industries selected in the "Made in China 2025" plan and received massive support from the state. The EV policy has turned out successful because it targeted the supply of raw materials by Chinese mining companies, the production of batteries by Chinese battery makers, and the local production of PHEVs and BEV using Chinese batteries. It was complemented by massive subsidies to consumers plus the exemption of restrictions imposed to drivers of conventional vehicles. China initiated a "raw material diplomacy" at the end of the 1990s when it encouraged its state and private companies to go global in selected targeted sectors (Reinhard Biedermann, 2018). China's aid and investment diplomacy in Africa, Latin America and Asia received a new impetus since 2013 with the Belt and Road initiative that extended the coverage and the financial resources at the disposal of Chinese investment abroad (Jetin, 2018). In a decade, it prompted China to a dominant position in almost all the segments of the EV value chain. China accounts for $60 \%$ of the global market. This success has its drawbacks: several battery makers are not competitive, and the cost of subsidies to customers became massive and not sustainable. In 2015, they were estimated at $\$ 8.4$ billion (Y. Wang, Sperling, Tal, \& Fang, 2017). The most popular models were cheap sub-compact cars with limited range. On March 26, 2019, the government revised its policy. Subsidies for cars with a driving range below $250 \mathrm{~km}$ were ended, and those for plug-in hybrids were cut by $55 \%$ to 10,000 yuan $(\$ 1,400)$. Subsidies for pure electric vehicles with a range of $250 \mathrm{~km}$ to $300 \mathrm{~km}$ were reduced from 34,000 yuan (around $\$ 5,000)$ to 18,000 yuan $(\$ 2,500)$ (Sun, 2019). It had an immediate negative effect on EVs sales, in a context of an overall decline of the Chinese automobile market since mid-2018 due to the slowdown of the Chinese economy, and the trade war with the USA (Shepherd, 2019). The Chinese automobile market has become mature after years of double-digit growth and is now entering a new phase of cyclical growth like all other large automobile markets. The present 
slowdown does not mean the end of the electric vehicle and the market will recover on more solid ground. It will also force Chinese battery makers to focus on advanced batteries and be more competitive. In the meantime, CATL became the world's biggest battery maker by installed capacity in 2019 and supplies many Japanese and German carmakers. CATL will open in 2021 a $\$ 2$ billion plant in Germany to be close to its customers, VW and BMW. The natural trend is that European and American carmakers will purchase their batteries from Chinese, Japanese and Korean battery companies to produce EVS in their domestic market. The question is, in an era of trade and political conflict between the great powers, whether American and European policymakers will let their future transportation system be dependent on a supply chain dominated by a few Chinese firms?

European and American carmakers follow their profit-maximising strategies and are inclined to respond positively. Whatever their nationality is, their priority is to secure suppliers able to provide them with batteries of the last generation at the cheapest cost and in large quantities. Carmakers believe that being at the frontier of innovation in batteries is sufficient to control the major part of the value chain. Most of them believe that packaging cells into modules and battery packs and developing the necessary software controllers is enough to maintain their leading role. They are ready to co-develop the battery they need with Chinese battery makers as much as they have done it previously with Korean and Japanese producers.

European carmakers were encouraged in this strategy because until recently, the EU did not have a coherent industrial policy to favour the development of a battery industry in Europe. Europe is highly dependent on imports of raw materials. As a consequence, the EU has adopted a "Raw material Initiative" in 2008 which considers cobalt, but not lithium, as a "critical material" although Europe produces almost no lithium, cobalt, nickel or graphite. The EU also set up a new economic diplomacy in 2008, to secure undistorted and free market access for resources (Reinhard Biedermann, 2016) that was mainly targeted to Africa under the policy of the "Africa-Europe Alliance". However, it appears that in practice few research projects funded by the EU "directly involve raw materials supply from outside of Europe" and only two focus exclusively on recycling end-of-life vehicles. However, they do not consider the entire portfolio of critical materials in the product (Løvika, Hagelüken, \& Wägera, 2018, p. 16). Until recently, there was no EU policy to foster the development of the European battery industry. It came only in 2017 when the French and German governments, with the EU Commission as a facilitator and the support of the European Investment Bank, launched the "European Battery Alliance" sometimes called the "Airbus of batteries". The primary motivation of policymakers is to avoid that the batteries, which account for up to $50 \%$ of the EV value chain, elude the European automobile industry and lead to massive loss of jobs and know-how. The privatepublic alliance is a group of 80 companies producing parts, batteries and vehicles with funding up to $€ 5$ billion. The objective is to be able to produce cells massively in Europe when the EV market takes off around 2025. To this aim, as many as 25 "Gigafactories" will have to be built across Europe by 2025. The first cell plant is being built in the Southwest of France by SAFT, a battery maker owned by the oil company Total. It forms a consortium with notably Siemens and Opel, the German subsidiary of PSA. TerraE, a German consortium led by BMZ, BASF, Varta and BMW will open a cell plant in Germany. Umicore, a Belgium chemical company, acquired a cobalt refinery in Finland from a US copper miner and has signed a long term supply agreement with the Korean battery maker LG Chem (Sanderson, 2019c). Finally, Northvolt, a Swedish battery maker set up by former Tesla executives, has won the backing of Volkswagen, Goldman Sachs, Ikea and BMW, helping the Swedish project to raise $\$ 1$ bn of fresh capital on top of a promised $€ 350 \mathrm{~m}$ loan by the European Investment Bank. The money is used to build a plant in northern Sweden and the second plant in Salzgitter, Lower Saxony, in co-operation with VW. 
VW has declared that the current agreements with battery makers can only fulfil 50 to $60 \%$ of its need by 2023. It leads VW to look for more joint ventures (Miller, 2019). Battery makers are reluctant to provide on their own all the necessary capital needed to expand the production capacities to the level expected by VW. If EVs are not successful, they would have to bear the full cost, while with a joint venture, risks are shared with carmakers. Nonetheless, the dominant opinion is that the EV market will take off in the 2020s and will become the second-largest after China. It is, therefore, necessary to invest now in battery capacities to be ready to supply carmakers. It is the motive of Tesla's decision, announced in November 2019, to open a new "Gigafactory" and a new engineering and design centre near Berlin to compete head-to-head with German premium brands. In summary, Europe is the second region of the world where public authorities adopt a comprehensive policy aimed at stimulating the rise of the EV market. The difference with China is that subsidies to the purchase of EVS is a national responsibility and can vary from one country to another. In France, they were in place since 2008. In Germany, they have been decided in 2016 and recently expanded when German carmakers decided to invest seriously in EVs (Buck, 2019). The second difference is that the private sector in Europe is much more independent from the state than in China and has to be convinced to embrace the EV strategy. It explains the delay of the EU to become genuinely involved in the formation of a European battery value chain.

This European initiative contrasts with the USA, where President Donald Trump has sought to relax standards on emissions.

In 2009, the US federal government awarded \$2.4 billion in grants under the American Recovery and Reinvestment Act to manufacturers of lithium-ion cells, battery packs, and materials (National Research Council, 2012). Nearly \$80 million a year for electric battery research and development have also been granted. To achieve the objective of one million PHEV sold by 2015 , the Obama administration recommended that the current $\$ 7,500$ tax credit for the purchase of a plug-in hybrid be converted into a $\$ 10,000$ rebate. Additional financial incentives were and still are available at the state level. However, EVs did not receive a direct push from the federal regulations "because they are performance standards that allow automakers to implement the most cost-effective technologies, which may not include PEVs" (Carley, Zirogiannis, Siddiki, Duncan, \& Graham, 2019, p. 4). The performance standards can be met by ICE vehicles because they are not stringent enough to the difference with the European standards, which were designed to achieve 30\% of EVs in 2030. The new "Safer Affordable Fuel-Efficient" (SAFE) rule proposed by the Trump administration would make things worse. California may find a legal way to maintain the previous regulations, and the USA could end up with two sets of fuel efficiency standards, which is not favourable to EVs diffusion. Because of the weakness in the promotion and support to the domestic EVs market, sales have been deceptive, and the US battery makers do not have the demand to drive significant scale cell production investment in the USA (Dougher, 2018). All batteries that equip EVs produced in the USA are made by Japanese and Korean battery makers with cells produced in the USA or imported from abroad (Coffin \& Horowitz, 2018, p. 11) ${ }^{19}$. The Department of Energy maintains an "advanced vehicle technologies research" programme which awards grants on electric powertrain components. In 2019, it awarded \$59 million to 43 projects among them \$US 2 million to GM on solid-state batteries. However, to the difference of the EU, there is no industrial policy to make sure that American battery makers will reap the benefits of this research. In practice, US carmakers will co-develop the next generation of batteries with foreign battery makers which may include Chinese firms. However, in place of a proper industrial policy, security concerns are leading the US authorities to catch up with China regarding the supply of raw materials. On December 2017, President Trump issued an executive order 's mineral executive order which led the Department of the Interior to publish a final list of 35 critical minerals in May 2018. These minerals are not only critical for the supply chain of 
laptops, cell phones, electric vehicles, and renewable energy technologies but also for national defence applications. Some of the minerals and technologies involved have a dual civil and military application (Humphries, 2019). Several decisions have been taken. The USA has recently signed a memorandum of understanding with Greenland to map out the country's reserves of critical metals. The new "US Development Finance Corporation" would let the US government take equity positions in mining projects and encouraging private sector investment (Dempsey \& Sanderson, 2019). New legislation to be adopted by the Senate would ease permitting requirements on new mines for lithium, graphite and other electric-vehicle supply chain minerals to challenge China's dominance (Scheyder, 2019). The US government is trying to encourage the creation of new companies to process rare earths in the USA after it stopped in 2015. In May 2019, Blue Line, a U.S.-based processor of rare-earth products, signed a memorandum of understanding with Australia's Lynas, the largest producer of rare-earth materials outside of China, to build a separation facility in the U.S. state of Texas (Tabeta, 2019). At the same, China has boosted its production of refined rare earths, pushing prices down. This move is interpreted as an attempt to undermine the construction of any new foreign separation plant to maintain China's monopoly. This shows the rising tensions between the great powers to secure enough supply of critical materials.

\section{Conclusion: "The one who conquers batteries will conquer the electrification of cars." 20}

In summary, this paper has shown that the rise of the EVS market will be rapidly confronted with a shortage of raw materials. China is the only country which is ready to face this issue thanks to the dominant position it has taken in the mining and processing of critical materials. Within a decade, its industrial policy led to the development of a competitive battery industry able to rival with the Japanese and Korean incumbents on global markets and even to supply them with critical refined materials. Chinese battery makers are now engaged in an R\&D race with their foreign competitors to be among the first to launch the new generation of solid-state batteries, which will have a higher energy density allowing a more extended range. With BYD, Geely and Great Wall, China has local carmakers able to market EVs at a large scale in the domestic market. However, China is still missing global brands which could extend their success abroad. Europe and the USA on the contrary, have active carmakers which believe that being at the edge of innovation in batteries will maintain their control of the whole value chain. Nevertheless, they do not have secured access to the vast quantities of critical materials needed for the mass production of batteries and their refining. Europe and the USA do have the scientific and technological capacities to develop the next generation of batteries, but they cannot produce them at massive scale. These weaknesses may become critical. If Chinese battery makers are the first to master the solid-state battery, on top of controlling the means to mass-produce them, they may be in a solid position to negotiate a large share of the value chain profitably. 
Tables and Figures

Table 1: Lithium-ion cathode configuration and corresponding specific energies

\begin{tabular}{|l|c|c|c|}
\hline Cathodes chemistries & $\begin{array}{c}\text { Energy } \\
\text { densities }\end{array}$ & Cycles & Applications \\
\hline LFP & 120 & 300 & $\begin{array}{l}\text { Large scale (grid storage), electric } \\
\text { buses, light trucks and small van, cars }\end{array}$ \\
\hline LMO & 140 & 820 & Power tools, medical devices \\
\hline NMC & 200 & 850 & E-bikes, EVs \\
\hline LCO & 200 & 1000 & Smartphones, laptops, cameras \\
\hline NCA & 245 & 950 & E-bikes, EVs \\
\hline \multicolumn{2}{|l}{ Source: Adapted from De Carlo et al., 2019}
\end{tabular}




\begin{tabular}{|c|c|c|c|c|c|c|c|}
\hline \multicolumn{8}{|c|}{ Table 2: BEVs models and main characteristics } \\
\hline Manufacturer & Model & $\begin{array}{l}\text { Battery } \\
\text { size } \\
\text { (kWh) }\end{array}$ & $\begin{array}{c}\text { Battery } \\
\text { Chemistry }\end{array}$ & Battery Supplier & $\begin{array}{l}\text { Vehicle } \\
\text { range } \\
\text { (mi) }\end{array}$ & $\begin{array}{c}\text { Vehicle } \\
\text { range } \\
(\mathrm{km})\end{array}$ & $\begin{array}{l}\text { Vehicle } \\
\text { cost, } \\
\text { USD }\end{array}$ \\
\hline Tesla & $\mathrm{S}$ & $60-100$ & NCA & Panasonic/Tesla & $\begin{array}{c}208- \\
315\end{array}$ & $\begin{array}{c}334- \\
508\end{array}$ & $\begin{array}{l}70,000- \\
109,000 \\
\end{array}$ \\
\hline Tesla & $\mathrm{X}$ & $60-100$ & NCA & Pansonic/Tesla & $\begin{array}{c}208- \\
315\end{array}$ & $\begin{array}{c}334- \\
508\end{array}$ & $\begin{array}{l}80,000- \\
115,000\end{array}$ \\
\hline BMW & i3 & $22-33$ & NMC & Samsung/Bosch & $80-114$ & $\begin{array}{l}129- \\
183\end{array}$ & $\begin{array}{l}43,500- \\
51,500\end{array}$ \\
\hline Nissan & Leaf & $24-30$ & $\begin{array}{l}\text { LMO } \\
\text { /(NMC) }\end{array}$ & $\begin{array}{c}\text { AESC and LG } \\
\text { Chem } \dagger\end{array}$ & $84-107$ & $\begin{array}{l}135- \\
172\end{array}$ & 29,000 \\
\hline Volkswagen & e-Golf & $24-35.8$ & NMC & $\begin{array}{c}\text { Panasonic } \\
\text { (Sanyo Div.) }\end{array}$ & $83-124$ & $\begin{array}{l}135- \\
200\end{array}$ & 29,000 \\
\hline Chevrolet & Spark & 19 & LFP & A123 & 82 & 132 & 10,400 \\
\hline Fiat & $00 \mathrm{e}$ & 24 & NMC & Samsung/Bosch & 87 & 140 & 32,500 \\
\hline Kia & Soul EV & 27 & NMC & SK Innovation & 90 & 145 & $\begin{array}{l}15,900- \\
35,950\end{array}$ \\
\hline Smart & $\begin{array}{c}\text { Fortwo } \\
\text { EV }\end{array}$ & 17.6 & NMC & LG Chem & 68 & 109 & $\begin{array}{l}14,650- \\
20,900\end{array}$ \\
\hline Ford & Focus EV & 35.5 & NMC & LG Chem & 100 & 160 & 29,000 \\
\hline BYD $^{*}$ & E6 & 75 & LFP & BYD & 200 & 322 & 52,000 \\
\hline Renau & Zoe & $41-52$ & NMC & $\overline{G^{0}}$ & 210 & 338 & 25,000 \\
\hline Mercedes & $\begin{array}{l}\text { B-Class } \\
\text { Electric }\end{array}$ & 28 & $\begin{array}{c}\text { NCA } \\
\text { /(NMC) }\end{array}$ & $\begin{array}{c}\text { Panasonic/Tesla } \\
\text { and SK } \\
\text { Innovation† }\end{array}$ & 85 & 137 & $\begin{array}{l}39,000- \\
47,000\end{array}$ \\
\hline Mitsu & 1 & 16 & LMO & Toshiba & 62 & 100 & 23,000 \\
\hline Honda* & Fit EV & 20 & LMO & Toshiba & 82 & 132 & 36,600 \\
\hline Toyota* & RAV4 EV & 41.8 & NCA & Panasonic/Tesla & 113 & 182 & 33,800 \\
\hline
\end{tabular}

* Discontinued Models. $\dagger$ In the process of changing suppliers

Source: Blomgren, 2017, Reinhardt et al., 2019, and author's own research 
Table 3: Materials' share in the main battery cathodes, in percentage

\begin{tabular}{|l|c|c|c|c|c|}
\hline \multicolumn{1}{|c|}{$\%$} & LCO & NCA & NMC-111 & NMC-622 & NMC-811 \\
\hline $\mathrm{Li}$ & 10,5 & 11,0 & 15,0 & 12,8 & 11,6 \\
\hline $\mathrm{Co}$ & 89,5 & 14,1 & 42,6 & 21,8 & 9,8 \\
\hline $\mathrm{Ni}$ & 0,0 & 74,9 & 42,4 & 65,3 & 78,5 \\
\hline $\mathrm{Mn}$ & 0,0 & 0,0 & 39,7 & 20,4 & 9,2 \\
\hline total & 100,0 & 100,0 & 100,0 & 100,0 & 100,0 \\
\hline
\end{tabular}

Source: Calculated from Olivetti et al., 2017, table 1 p. 231 
Table 4: Material demand and supply and material depletion in the year 2030

\begin{tabular}{|c|c|c|c|c|c|c|c|c|c|}
\hline 2030, kt & \multicolumn{2}{|c|}{ IEA scenario for 2030} & \multirow{2}{*}{$\begin{array}{c}\text { USGS } \\
2018 \text { mining }\end{array}$} & \multicolumn{2}{|c|}{ Availability (Mt) } & \multicolumn{2}{|c|}{$\begin{array}{c}\text { Lifespan (years), New } \\
\text { Policy scenario }\end{array}$} & \multicolumn{2}{|c|}{$\begin{array}{l}\text { Lifespan (years), } \\
30 @ 30 \text { scenario }\end{array}$} \\
\hline & New Policy & 30@30 & & Reserve & Resource & Reserve & Resource & Reserve & Resource \\
\hline Lithium & 155 & 320 & 85 & 14 & 62 & 58 & 258 & 35 & 153 \\
\hline Cobalt & 170 & 350 & 140 & 7 & 25 & 22 & 81 & 14 & 51 \\
\hline Nickel & 850 & 1750 & 2300 & 89 & 130 & 28 & 41 & 22 & 32 \\
\hline Manganese & 155 & 350 & 18000 & 760 & n.a. & 42 & n.a. & 41 & n.a. \\
\hline
\end{tabular}

Note: Adapted from Harvey, 2018, p 665. Battery chemistry mix composed of $10 \%$ of NCA, 40\% NMC 622 and $50 \%$ NMC 811 for 2030. Source: IEA, Global EVs Outlook 2019, Figure 3.5, p 133, and USGS 2019 


\section{References}

Ajanovic, A., \& Haas, R. (2018). Electric vehicles: solution or new problem? Environment, Development and Sustainability, 20(1), 7-22.

Amatucci, M., \& Spers, E. E. (2010). The Brazilian biofuel alternative. International Journal of Automotive Technology and Management, 10(1), 37-55.

Azevedo, M., Campagnol, N., Hagenbruch, T., Hoffman, K., Lala, A., \& Ramsbottom, O. (2018). Lithium and Cobalt: a tale of two commodities. Retrieved from

Barrera, P. (2019, May 7th, 2019). Top Lithium-mining Companies. Retrieved from https://investingnews.com/daily/resource-investing/battery-metals-investing/lithium-investing/toplithium-producers/

Behrmann, E., Farchy, J., \& Dodge, S. (2018). Hype Meets Reality as Electric Car Dreams Run Into Metal Crunch. Retrieved from https://www.bloomberg.com/graphics/2018-cobalt-batteries/

Berggren, C., \& Kågeson, P. (2017). Speeding up electro-mobility: How to electrify half of new car sales by 2030. Retrieved from Bruxels:

Biedermann, R. (2016). The European Union's Raw Materials Diplomacy: Market Access and Development? European Foreign Affairs Review, 21(1), 115-134. Retrieved from http://www.kluwerlawonline.com/document.php?id=EERR2016008

Biedermann, R. (2018). China's Raw Materials Diplomacy and Governance Cycle: Toward Sustainable Mining and Resource Extraction? Issues \& Studies, 54(04), 1840009. doi:10.1142/s101325111840009x

Blagoeva, D., C., P., Wittmer, D., Huisman, J., \& Pasimeni, F. (2019). Materials dependencies for dual-use technologies relevant to Europe's defence sector. Retrieved from Luxembourg: https://ec.europa.eu/jrc/en/publication/eur-scientific-and-technical-research-reports/materialsdependencies-dual-use-technologies-relevant-europes-defence-sector

Blomgren, G. E. (2017). The development and future of lithium ion batteries. Journal of The Electrochemical Society, 164(1), A5019-A5025.

Board, C. A. R. (2019). Zero-Emission Vehicle Program. Retrieved from https://ww2.arb.ca.gov/ourwork/programs/zero-emission-vehicle-program/about

Boyer, R., \& Freyssenet, M. (2002). The productive models: the conditions of profitability: Palgrave Macmillan.

Buck, T. (2019, November 5, 2019). Germany to increase subsidies for electric vehicles. Financial Times.

Carley, S., Zirogiannis, N., Siddiki, S., Duncan, D., \& Graham, J. D. (2019). Overcoming the shortcomings of U.S. plug-in electric vehicle policies. Renewable and Sustainable Energy Reviews, 113, 109291. doi:https://doi.org/10.1016/j.rser.2019.109291

Cheung, A. (2017). The EV Bandwagon Is Accelerating, But Is It Unstoppable? Retrieved from https://about.bnef.com/blog/cheung-ev-bandwagon-accelerating-unstoppable/

Ciez, R. E., \& Whitacre, J. (2016). The cost of lithium is unlikely to upend the price of Li-ion storage systems. Journal of Power Sources, 320, 310-313.

Ciez, R. E., \& Whitacre, J. (2017). Comparison between cylindrical and prismatic lithium-ion cell costs using a process based cost model. Journal of Power Sources, 340, 273-281.

Coffin, D., \& Horowitz, J. (2018). The Supply Chain for Electric Vehicle Batteries. Journal of International Commerce and Economics(December), 1-21.

Coles, I. (2019, June 21). Strategic minerals - the new global battleground. Financial Times.

Commission, E. (2019a). Critical raw materials. Retrieved from https://ec.europa.eu/growth/sectors/rawmaterials/specific-interest/critical_en

Commission, E. (2019b). Post-2020 CO2 emission performance standards for cars and vans. Retrieved from https://ec.europa.eu/clima/policies/transport/vehicles/regulation_en

Commons, H. o. (2019). Clean Growth: Technologies for meeting the UK's emissions reduction targets (1454). Retrieved from London: https://www.parliament.uk/business/committees/committees-a-z/commonsselect/science-and-technology-committee/inquiries/parliament-2017/clean-growth-emissions-17-19/

Council, N. R. (2012). Building the U.S. Battery Industry for Electric Drive Vehicles: Progress, Challenges, and Opportunities: Summary of a Symposium. Washington, DC: The National Academies Press.

Curry, C. (2017). Lithium-ion Battery Costs and Market.

DeCarlo, S., \& Matthews, D. (2019). More Than a Pretty Color: The Renaissance of the Cobalt Industry. Journal of International Commerce and Economics (February). Retrieved from http://www.usitc.gov/journals

Dempsey, H., \& Sanderson, H. (2019, September 27). US seeks to curb Chinese dominance in critical minerals. Financial Times.

Dougher, C. (2018). Breaking down the lithium-ion cell manufacturing supply chain in the u.s. to identify key barriers to growth. (Master Master of Environmental Management degree ). Duke University, 
Economist, T. (2017, August 12). After electric cars, what more will it take for batteries to change the face of energy? Retrieved from https://www.economist.com/briefing/2017/08/12/after-electric-cars-what-morewill-it-take-for-batteries-to-change-the-face-of-energy

Environment, T. (2019). Electric surge: Carmakers' electric car plans across Europe 2019-2025. Retrieved from Brussels, Belgium: https://www.transportenvironment.org/publications/electric-surge-carmakerselectric-car-plans-across-europe-2019-2025

Fessler, D. C. (2019). The Energy Disruption Triangle: Three Sectors That Will Change How We Generate, Use, and Store Energy. New York, United States: John Wiley \& Sons Inc.

Finance, B. N. E. (2019). Electric Vehicle Outlook 2019. Retrieved from https://about.bnef.com/electric-vehicleoutlook/\#toc-download

Fréry, F. (2000). Un cas d'amnésie stratégique: l'éternelle émergence de la voiture électrique. Paper presented at the IXème Conférence Internationale de Management Stratégique Montpellier.

Freyssenet, M. (2011). Three possible scenarios for cleaner automobiles. International Journal of Automotive Technology and Management, 11(4), 300-311.

Freyssenet, M. (2012). The Second Automotive Revolution is under Way: Scenarios in Confrontation. In The Greening of the Automotive Industry (pp. 304-322): Springer.

Freyssenet, M. (Ed.) (2009). The second automobile revolution: trajectories of the world carmakers in the 21 st century. Basingtoke, New York Palgrave Macmillan.

Harvey, L. D. D. (2018). Resource implications of alternative strategies for achieving zero greenhouse gas emissions from light-duty vehicles by 2060. Applied Energy, 212, 663-679.

Helbig, C., Bradshaw, A. M., Wietschel, L., Thorenz, A., \& Tuma, A. (2018). Supply risks associated with lithium-ion battery materials. Journal of Cleaner Production, 172, 274-286.

Hornby, L., \& Sanderson, H. (2019, June 4). Rare earths: Beijing threatens a new front in the trade war. Financial Times.

Hume, N. (2019, September 2). Nickel hits five-year high as price surge continues. Financial Times.

Humphries, M. (2019). Critical Minerals and U.S. Public Policy. Retrieved from Washington D.C.: www.crs.gov.

IEA. (2019). Global EV Outlook 2019: Scaling-up the transition to electric mobility. Paris: International Energy Agency.

Inagaki, K., Henry, S., \& Charles, C. (2018, February 24). global carmakers race to lock in lithium for electric cars. Financial Times.

Jaffe, S. (2017). Vulnerable Links in the Lithium-Ion Battery Supply Chain. Joule, 1(2), 225-228. doi:https://doi.org/10.1016/j.joule.2017.09.021

Jetin, B. (2015). Global automobile demand : major trends in mature economies. Houndmills, Basingstoke Hampshire: Palgrave Macmillan.

Jetin, B. (2018). 'One Belt-One Road Initiative'and ASEAN Connectivity: Synergy Issues and Potentialities. In B. R. Deepak (Ed.), China's Global Rebalancing and the New Silk Road (pp. 139-150). Singapore: Springer.

Kong, T. Y. (2016). New Energy Vehicles Industry in China: Developments and Challenges. East Asian Policy, 8(3), 87-99. doi:10.1142/s1793930516000325

Lebedeva, N., Di Persio, F., \& Boon-Brett, L. (2017). Lithium ion battery value chain and related opportunities for Europe. Retrieved from Luxembourg: https://ec.europa.eu/jrc/en/publication/eur-scientific-andtechnical-research-reports/lithium-ion-battery-value-chain-and-related-opportunities-europe

Lex. (2019, August 15). Nickel/Indonesia, electric vehicles afar. Financial Times.

Liu, D., Gao, X., An, H., Qi, Y., Sun, X., Wang, Z., . . . Jia, N. (2019). Supply and demand response trends of lithium resources driven by the demand of emerging renewable energy technologies in China. Resources, Conservation and Recycling, 145, 311-321.

Løvika, A. N., Hagelüken, C., \& Wägera, P. (2018). Improving supply security of critical metals: Current developments and research in the EU. Sustainable Materials and Technologies, 15, 9-18.

Mayyas, A., Steward, D., \& Mann, M. (2019). The case for recycling: Overview and challenges in the material supply chain for automotive li-ion batteries. Sustainable Materials and Technologies, 19, e00087.

McGee, P. (2018, August 6). Car emissions scandal: loopholes in the lab tests. Financial Times.

McKerracher, C. (2018). BP's Energy Outlook and the Rising Consensus on EV Adoption. Retrieved from https://about.bnef.com/blog/bps-energy-outlook-and-the-rising-consensus-on-ev-adoption/

Miller, J. (2019, September 24). Volkswagen keen to forge battery technology partnerships. Financial Times.

Muniz, S. T. G., \& Belzowski, B. M. (2017). Platforms to enhance electric vehicles' competitiveness. International Journal of Automotive Technology and Management, 17(2), 151-168.

Nassar, N. T., Graedel, T. E., \& Harper, E. (2015). By-product metals are technologically essential but have problematic supply. Science advances, 1(3), e1400180. 
Nieder, T., \& Püttner, A. ( 2019). Data on Electromobility. Retrieved from https://www.zsw-bw.de/en/mediacenter/data-service.html\#c6700. Retrieved October 12, 2019, from Zentrum für Sonnenenergie und Wasserstoff, ZSW https://www.zsw-bw.de/en/media-center/data-service.html\#c6700

Nykvista, B., Spreib, F., \& Nilssona, M. (2019). Assessing the progress toward lower priced long range battery electric vehicles. Energy Policy, 124, 144-145. doi:https://doi.org/10.1016/j.enpol.2018.09.035

OICA. (2019). Sales of new vehicles 2005-2018. Retrieved from http://www.oica.net/category/sales-statistics/

Olivetti, E. A., Ceder, G., Gaustad, G. G., \& Fu, X. (2017). Lithium-ion battery supply chain considerations: analysis of potential bottlenecks in critical metals. Joule, 1(2), 229-243.

Ortego, A., Valero, A., Valero, A., \& Restrepo, E. (2018). Vehicles and critical raw materials: A sustainability assessment using thermodynamic rarity. Journal of Industrial Ecology, 22(5), 1005-1015.

Petroleum, B. (2018). BP Energy Outlook. Retrieved from

Proff, H. (2011). What will happen to Brazilian automotive subsidiaries after their parent companies make the transition to electric mobility? International Journal of Automotive Technology and Management, 11(4), 356-375.

Reinhardt, R., García, B. A., Casals, L. C., \& Domingo, S. G. (2019). A critical evaluation of cathode materials for lithium-ion electric vehicle batteries. In J. L. Ayuso Muñoz, J. L. Yagüe Blanco, \& S. Capuz Rizo (Eds.), Project Management and Engineering Research (pp. 99-110). Heidelberg: Springer.

Rosendahl, K. E., \& Rubiano, D. R. (2019). How effective is lithium recycling as a remedy for resource scarcity? Environmental and Resource Economics, 74(3), 985-1010.

RSC. (2017). Periodic Table. Retrieved from http://www.rsc.org/periodic-table/

Sanderson, H. (2019a, July 7). Congo, child labour and your electric car. Financial Times.

Sanderson, H. (2019b, May, 22). Electric battery cars: China powers the battery supply chain. Financial Times.

Sanderson, H. (2019c, September 25). Europe's batteries push promises much-needed relief for investors. Financial Times.

Sanderson, H. (2019d, June 29). Plummeting cobalt price takes toll on Democratic Republic of Congo. Financial Times.

Schade, W., \& Mader, S. (2016). Analysis of the battery value chains with regard to the German industry and the global context. Retrieved from Karlsruhe:

Scheyder, E. (2019, May 2, 2019 ). U.S. seeks to challenge China's electric-vehicle supply chain dominance. Retrieved from https://www.reuters.com/article/us-usa-lithium-electric-exclusive/exclusive-u-s-seeksto-challenge-chinas-electric-vehicle-supply-chain-dominance-idUSKCN1S81EO

Shepherd, C. (2019, October 14). China new energy vehicle sales drop 34\%. Financial Times.

Sun, N. (2019). EV subsidy cuts give Chinese automakers more reason to fret. Nikkei Asian Review.

Tabeta, S. (2019, November 10). Rare earths wars: China expands production to squeeze US entrants Nikkei Asian Review.

Tanaka, A., Kawakami, T., \& Omoto, Y. (2018, November 14). Battery wars: Japan and South Korea battle China for future of EVs. Nikkei Asian Review.

VW. (2019, October 19, 2019). Volkswagen plans 22 million electric vehicles in ten years. Retrieved from https://www.volkswagen-newsroom.com/en/press-releases/volkswagen-plans-22-million-electricvehicles-in-ten-years-4750

Wang, H., \& Kimble, C. (2011). Leapfrogging to electric vehicles: patterns and scenarios for China's automobile industry. International Journal of Automotive Technology and Management, 11(4), 312-325.

Wang, Y., Sperling, D., Tal, G., \& Fang, H. (2017). China's electric car surge. Energy Policy, 102, 486-490.

Wentker, M., Greenwood, M., \& Leker, J. (2019). A Bottom-Up Approach to Lithium-Ion Battery Cost Modeling with a Focus on Cathode Active Materials. Energies, 12, 1-18.

Wilson, T., \& Hume, N. (2019, May 8). Pressure builds on mining industry over supply chains. Financial Times.

\footnotetext{
${ }^{1}$ Source: OICA, International Organization of Motor Vehicle Manufacturers. Author's calculations based on sales statistics of all types of vehicles for the period 2010-18.

${ }^{2}$ A fuel cell electric vehicle (FCEV) is a type of EV that uses hydrogen, via a fuel cell, to power an electric motor. In 2018, there were 1 FCEV per 460 PHEVs and BEVs (IEA, 2019).

${ }^{3}$ This agreement aims to limit the temperature rise to below $2^{\circ} \mathrm{C}$ and to pursue efforts to go further to $1.5^{\circ} \mathrm{C}$.

${ }^{4}$ The standards require carmakers to reduce $\mathrm{CO} 2$ emissions from all new cars by $15 \%$ in 2025 and $37.5 \%$ in 2030 , and for all new vans by $15 \%$ reduction from 2025 on and $31 \%$ reduction from 2030 compared to 2021 levels. These will come into force on 1 January 2020. Any carmaker that misses the target faces a punitive fine of $€ 95$ per gramme over the target, multiplied by the number of cars sold in the EU.

${ }^{5}$ Carmakers earn tradable credits when they produce "new energy" vehicles. In 2019, they must produce or purchase the equivalent to $10 \%$ of their internal-combustion engines sales. In 2020, the requirement is $12 \%$. They are subject to sanctions if they fail to acquire enough credits.
} 
${ }^{6}$ In the case of California, it is estimated that "about 8 per cent of California new vehicle sales in 2025 will be ZEVs and plug-in hybrids" (California Air Resources Board, accessed October 18, 2019);

${ }^{7}$ For instance, the British government's objectives state that "between $50 \%$ and $70 \%$ of new car sales and up to $40 \%$ of new van sales must be ultra-low emission by 2030; that sales of new conventional petrol and diesel cars and vans by 2040 will be banned; and that "almost every car and van" must be zero-emission by 2050" (House of Commons, 2019).

${ }^{8}$ include battery-electric vehicles (BEV) and other electric vehicles (such as Plug-in Hybrid electric vehicles, PHEV)

9. The EV30@30 Scenario accounts for the pledges of the EVI EV30@30 Campaign to reach 30\% market share for electric vehicles (EVs) by 2030 (excluding two/three-wheelers) (IEA, 2019).

${ }^{10}$ The differences lie in the hypotheses regarding batteries cost fall, improvements in average internal combustion engine efficiency, and the size of the global vehicle fleet in 2040 (McKerracher, 2018).

${ }^{11}$ Nykvista, Spreib, and Nilsson (2019, p. 149), find a battery cost-share ranging from $22 \%$ to $28 \%$ in 2030 for an average priced car with a range of $321 \mathrm{~km}$ (200 miles). It is based on a moderate scenario of 60 million BEVs and 120 million EVs fleet.

${ }^{12}$ Nykvist et al's estimations are based on the assumption of a 60 million BEV fleet in 2030, which amounts to $6 \%$ of the total fleet. The average BEV has a $322 \mathrm{~km}$ (200 miles) range.

13 "The smaller the battery pack, the larger the relative fixed costs associated with it such as battery management system and casing" (IEA, 2019, p 168).

${ }^{14}$ The numbers denote the ratio of Nickel (Ni), Cobalt (Co), and Manganese (Mn).

${ }^{15}$ A resource is defined by the USGS (2019, p. 195) as "a concentration of naturally occurring solid, liquid, or gaseous material in or on the Earth's crust in such form and amount that economic extraction of a commodity from the concentration is currently or potentially feasible." A reserve base is "that part of an identified resource that meets specified minimum physical and chemical criteria related to current mining and production practices, including those for grade, quality, thickness, and depth" (USGS, p. 196).

${ }^{16}, 66 \%$ of the cobalt used by the EU comes from Finland. However, Russia accounts for $31 \%$. The EU is, therefore, not totally immune from political risk. (Source: Wentker et al., 2019, p 9).

${ }^{17}$ This has already happened in 2010 after the government of Japan acquired the Seikoku islands from its private Japanese owner. These islands are claimed by China, which retaliated by suspending the exports of rare earths to Japan.

${ }^{18}$ In China, the official terminology uses the term "new energy vehicles".

${ }^{19}$ The only exception is the German company Bosch, which assembles batteries in Michigan for Fiats produced in Mexico. See Coffin and Horowitz, Table 3, p. 11.

${ }^{20}$ Toyota Executive Vice President Shigeki Terashi, in charge of the company's battery business, quoted in (Tanaka, Kawakami, \& Omoto, 2018) 